\title{
CONCEPTUAL FRAMEWORK OF HUMAN RESOURCE MANAGEMENT IN TOURISM EDUCATION OF THE REPUBLIC OF KAZAKHSTAN
}

\author{
Alina PESTOVA* \\ Kazakh Academy of Sports and Tourism, Department of Tourism and Service, Almaty, Republic of Kazakhstan, e-mail: 1846339@mail.ru \\ Anastassiya GUBARENKO \\ Kazakh Academy of Sports and Tourism, Department of Tourism and Service, Almaty, Republic of Kazakhstan, e-mail: gerseda@mail.ru \\ Tatyana IMANGULOVA \\ Kazakh Academy of Sports and Tourism, Department of Tourism and Service, Almaty, Republic of Kazakhstan, e-mail: tanya_geo@mail.ru
}

Saltanat USSUBALIYEVA

Kazakh Ablaikhan University of International Relations and world Languages, Department of International Tourism Management, Almaty, Republic of Kazakhstan, e-mail: salta-74@mail.ru

\section{Amina UAISOVA}

Kazakh Ablaikhan University of International Relations and world Languages, Department of International Tourism Management, Almaty, Republic of Kazakhstan, e-mail: amina.uaisova@mail.ru

\begin{abstract}
Citation: Pestova, A., Gubarenko, A., Imangulova, T., Ussubaliyeva, S., \& Uaisova, A. (2021). CONCEPTUAL FRAMEWORK OF HUMAN RESOURCE MANAGEMENT IN TOURISM EDUCATION OF THE REPUBLIC OF KAZAKHSTAN. GeoJournal of Tourism and Geosites, 38(4), 1005-1010. https://doi.org/10.30892/gtg.38403-737
\end{abstract}

\begin{abstract}
In the article, the authors present an overview of the historical line of development of the human resource management (HRM) system in the Republic of Kazakhstan, define the conceptual framework of modern sustainable development of HR management in tourism, and form focus area in its development. In the course of the research, a survey has been conducted among the entities of the tourism industry of Kazakhstan, which was attended by representatives of the business environment of the near and far abroad countries. The results of the survey among specialists in the tourism industr $y$ have formed the basis of large-scale research. The strengths and weaknesses of HRM in tourism of the Republic of Kazakhstan have been identified; the analysis of modern trends in HRM of the country reflected in regulatory and legislative documents, state demands, the business and social environment have been carried out. The authors propose a three-stage model of mastering the HR competencies in the tourism education of the Republic of Kazakhstan.
\end{abstract}

Key words: human resource management, tourism, management, manager, education, tourism education

\section{INTRODUCTION}

Currently, the world tourism industry is undergoing many negative events related to the COVID 19 pandemic. The borders of a large number of countries have been partially or completely closed for more than a year or are still remain closed. On the one hand, the paralyzed world tourism industry has caused great damage to the economy of numerous countries, but on the other hand, the focus has been shifted to domestic tourism, when active research and rational use of the tourist and recreational potential of countries and regions should be organically combined with the professional training of tourism specialists and their competent management within both tourist organizations and the entire industry as a whole. The high quality of trained specialists, the availability of their competencies in the field of professional activity, practice-oriented knowledge, skills in the field of organization management, career-building skills, strategic planning, etc., will allow forming that layer of professionals that is commonly called human capital.

The trends of recent years prove that the human resource management system in tourism of the Republic of Kazakhstan requires transformation. In their Addresses to Kazakhstanis, Elbasy N. A. Nazarbayev and the current President of the Republic Kassym-Jomart Tokayev have repeatedly noted the importance of this issue: "... it is right when professionalism is at the heart of any business... The goal of the national intelligentsia at the new stage is to adopt new national principles, as well as to contribute to improving the quality of the nation" (Tokayev, 2020). In addition, the development of human potential is a global task. The World Bank Group is already implementing the Human Capital Project in which, as of January 2021, 79 countries with different income levels are developing strategic approaches that will allow them to radically improve the results in the field of human capital development. International human resource (HR) management organizations are actively developing, for example, Hill International, that is located in 72 offices in 36 countries, including Kazakhstan, can be called a leader in this field. The goals of these and many other organizations in the field of HRM (human resource management) are to

\footnotetext{
* Corresponding author
} 
increase human resource efficiency, through their development and the formation of high-quality human potential. The tourism industry is one of the most industrial sectors driving the global economy at the present time (Bazazo and Alananzeh, 2020). Therefore, the issue of training professional tourist personnel with the skills of managing the human resources system in the conditions of modern society is relevant for the entire world tourism community. While the production sector offers well-qualified employees, for example, graduates, with an exciting and dynamic career, international career opportunities, the tourism industry also needs a huge number of operational employees (Karamova, 2014). Qualified and trained human resources are a real asset of a company (Mahmoud et al., 2021). Now, three main stages of the reform of this process have been formed in the republic, suggesting a systematic transition from an exposition-mixed model to a career model based on the priority of the principle of meritocracy, efficiency and accountability to society.

\section{MATERIALS AND METHODS}

This research is based on classical and modern works on HR management, which together allowed us to define the term: "HRM is a specialized function in organizations aimed at managing hired labor" (Boxall et al., 2021), and for the first time, it appeared in American management, reflecting the change in the role and place of a person in the labor process. At the same time, the most common approach is that human resource management is "a strategic and logically consistent approach to managing the most valuable asset of an enterprise: employees who collectively and individually contribute to solving the tasks of the enterprise" (Armstrong, 2004). In the process, the materials of specialists analyzing the human resource management system in tourism and service at the international and regional levels have been studied, which show that HRM activities play a vital role in improving the efficiency of businesses, expanding their market share, personal initiatives and innovations in the service sector (Ardito and Messeni, 2017; Anderson et al., 2014; Mahmoud et al., 2021). A retrospective analysis, an analysis that represents the reflection of past trends, allowed us to identify the principal periods in the establishment and development of the human resource management system in the world, allowed drawing an analogy of this process within the framework of the formation of HRM in Kazakhstan, with the isolation of tourism as a separate direction in management activities that has special features. Thus, human resource management in tourism in Kazakhstan was considered in the context of tourism management (Erdavletov, 2000). Today, tourism education is formed on the principles of the international education quality system-UNWTO Ted. Qual, where personnel management is of particular importance (Abdikarimova at al, 2020). Modern research in the field of HRM is aimed at implementing a personnel management system at real sector enterprises (Olimova, 2021), as well as in the educational environment as an independent cycle of disciplines (Armstrong, 2019), which is an integral advantage and competitiveness of any enterprise and organization (Cheglakova and Chislina, 2019). Scientists notes that in modern conditions of globalization of markets and transnationalization of economic relations, as well as a significant level of intellectualization of modern business processes, human capital and education in business and in other spheres is a decisive factor in the competitiveness of national economy on the different levels (Arpentieva et al., 2020). The role of human capital and the human resource management system is increasing, today it is designated as a key one in the development of entire regions (Israilova, 2020), as well as in the management of their innovative potential (Hamdamov, 2020).

The basics of case studies were applied to accurately define the status of the human resource management system in tourism and tourism education of the Republic of Kazakhstan. A case study is an in-depth study of a certain social unit of which results give a broad overview and deep understanding of the social unit under study. The research subjects might be individuals, groups, institutions, or communities (Vasyuchkova et al., 2017). The research has been conducted within the framework of the professional activities of tourism and education entities. Thus, a survey has been prepared, including questions, the answers to which allowed analyzing the state of HRM in tourism and the process of training specialists for the tourism industry. The professional survey was attended by tourism companies and universities that train tourism managers in Kazakhstan, Lithuania, Ukraine, and Russia. Survey is a key method of collecting empirical information in sociological research (Shapiro, 2017). The survey in an interactive form in Google form allows respondents, regardless of their place of residence, to take part in the survey, and the authors-researchers to make an exact choice to whom the questionnaire should be sent. Thus, the main algorithm of actions that contribute to the introduction of a human resource management system in tourism education can be presented in the following steps: 1) Identification of the need for the formation of competencies in the field of human resource management among university graduates according to the educational program (OP) "Tourism" at different levels, by means of analyzing responses to a professional survey among subjects of the tourism industry and employers, requests of the state and society. 2) Determination of the key results of training and the formation of relevant disciplines at different levels of continuing tourism education; 3 ) Analysis of the results obtained, through actual feedback from actual employers.

\section{RESULTS AND DISCUSSION}

The historical line of HRM development represents several basic periods, which are distinguished by an intensive change in the role of a person, a professional in various areas of the economy. So, the period from the end of the XIX to the beginning of the XX century is characterized by the establishment of the conceptual framework of HRM (human resource management) in the works of scientists-economistsand (Rudenko et al., 2015). Further, with each decade of the twentieth century, the role of high-quality human resources has increased and the gradual transformation to the concept of human capital, which in the XXI century has become the most consistent definition. In the route of its historical development, HRM in the Republic of Kazakhstan is a process that has crossed almost all stages at an "accelerated" pace in the last 50 years. If at the beginning of the twentieth century, human resources were quantitative, when the headcount was of supreme importance, then in the period from the $50 \mathrm{~s}$ to the $80 \mathrm{~s}$ of the twentieth century, an essential turning point 
occurs, when qualitative characteristics, if not superior, then become as valuable as quantitative ones. Since the 90s, a crucial period of formation of the national vector of development of the economy, society and management has begun in the republic. Since then, HR management has begun its active development, innovative methods of managing organizations have appeared at all levels, from the state system to entities and professionals in all areas of society, including tourism. At present, the human resource management system has its own industry directions that reflect the unique features of diverse areas of the economy, this of course also applies to tourism, as one of the most communicative areas of professional activity, lying in the "person - person" level, where human resources represent an essential capital that requires continuous investments both at the professional level and at the level of training specialists. The trends of the last 5 years are the introduction of HR management principles into the educational process in a big number of areas, including in the tourism education of the republic. Figure 1 shows the key stages of HRM development in the tourism of the Republic of Kazakhstan, each of which has its own characteristics and creates a modern conceptual framework.

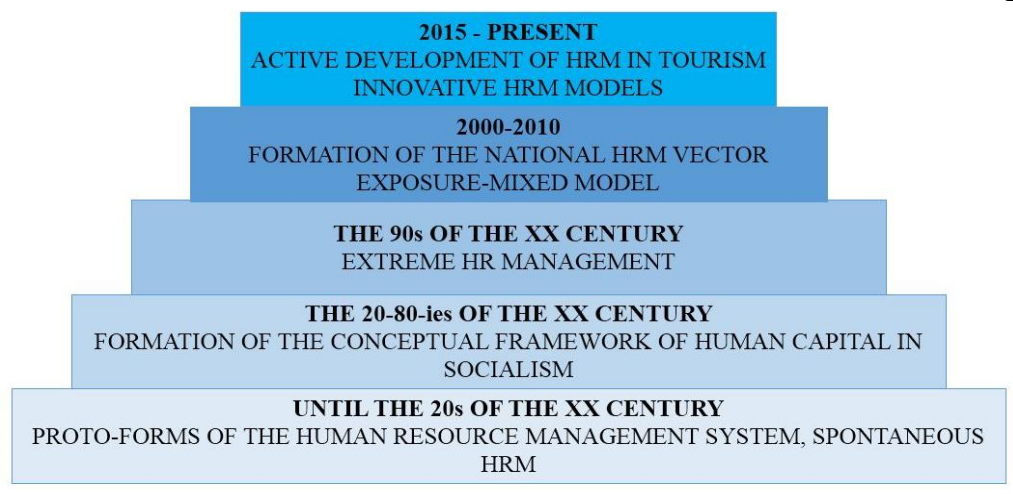

Figure 1. The key stages of the development of the conceptual framework of HRM (human resource management) in tourism of the Republic of Kazakhstan (Source: compiled by the author)
Thus, the key stages of the development of personnel management create a particular logical sequence of interrelated elements and events. Each of the stages of the development of the human resource management system in tourism in the Republic of Kazakhstan has specific features that allowed forming an innovative approach to HRM, as well as to isolate the direction of tourism as a separate one that has distinctive features and requires an integrated approach:

- The first stage: until the 20 s of the twentieth century, human resource management in the republic was spontaneous. Nomadic and seminomadic lifestyles impacted the quality of people's mobility, when every member of society understood his place, fully owned the required knowledge and skills in a specific activity, craft.

The Kazakh society intuitively held and applied the principles of HR management, but did not have a scientific background, we can describe this period as a proto-form.

- The second stage: the period of the 20-80s of the twentieth century, the conceptual framework of HRM was formed in the conditions of socialism. This period was full of numerous concepts, directed by the principle of constant improvement of human resource productivity. It is then that a person from a resource starts transforming into capital. Since the training of a specialist becomes a priority task in the economic development of the whole country, and getting a profession is the obligation of each citizen.

- The third stage: the 90s of the twentieth century, the period of crisis of all economic areas, when the global restructuring affected all spheres of society. There is a redistribution of forces and resources, new sources of knowledge about management, motivation, staff work, etc. are opening up. Scientists in the field of HRM describe this period as extreme, which allowed them to accumulate notable experience in managing extreme situations (Morgunov, 2011).

- The fourth stage: in the 2000s and 2010s, there is an active search for methods of establishment and development of human resources. HRM specialists examine not only the current world concepts but also try creating a unique, national vector of development that would join the theoretical and methodological grounds of human resource management and modern methods that have proven their practical effectiveness. Since then, a large number of research works in HR management have appeared in all spheres of the economy, government bodies, and education.

- The fifth stage: from 2015 to the present, it is characterized by systematic HRM developments in tourism and a career development model. A model of a specialist in the tourism industry has been built, in which the skills of the human resource management system are mandatory. So, in 2017, 2019, Atameken - the National Chamber of Entrepreneurs - developed the Passport of Profession project, including in the tourism industry. The first HR forum took place in 2019. The purpose of the forum is to contribute to the development of the human potential of state bodies by the introduction of the best technologies in the field of strategic management and staff to create a permanent educational platform for the training of highly qualified HR managers. HR award is held annually, which presented the best projects on personnel management in four areas: digital solution - IT projects on the development of business; save-well-being projects - case studies on the improvement of working conditions, reflecting the activities of companies focused on the well-being of workers; level up projects -training and motivating employees; be cool projects focused on work with schoolchildren, students and young professionals (https://wowhr.kz/). Recently, a project for the development of HR management in the Republic of Kazakhstan has been created in collaboration with Hill International, etc.

During the research, we have conducted the survey among specialists in the tourism industry, which was attended by tourism entities of Kazakhstan, Lithuania, Russia, and Ukraine to discover the need to change the approach to training professionals with HR planning and management skills. Today, there is a problem with the quality of the staff produced for the tourism industry. The professional survey consisted of a set of questions that show both the trends of modern HRM (human resource management) in tourism and reveal the basic needs of the entities of the tourism industry in the personnel training. The analysis of the answers unveiled the need for training specialists with personnel management skills, forming a portal for 
finding qualified employees, and constant professional development within the framework of career building (Figure 2).

Hence, $46 \%$ of respondents, when asked about the higher education among specialists, noted the necessity to master higher education under the educational program in tourism, which shows the need for highly qualified professionals with the skills of an HR manager who meet the standards of the state, society, and specialty (Figure 2). Meanwhile, along with the language skills, there is a need for the ability to work with personnel, manage and organize their activities (Figure 3). Therefore, at present, the entities of the tourism industry define management and HR (human resource) skills as one of the most valuable for a modern specialist.

This refers both to workers who are already working and to graduates who have recently completed the Tourism educational program. This trend unveils the principal criterion for the development of modern HRM in the tourism of the
What level of education is more important when choosing a specialist for tourism enterprises?

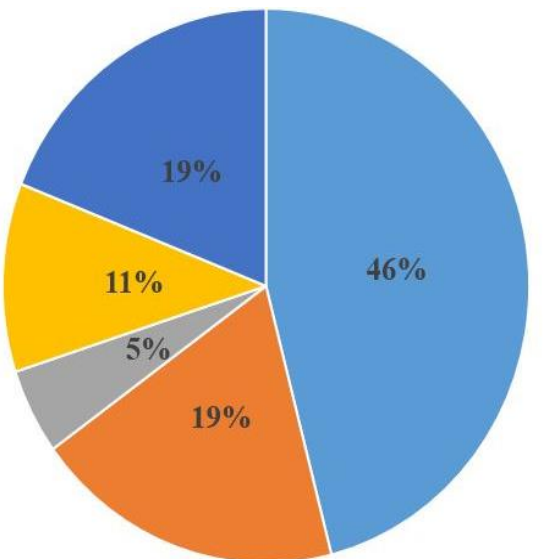

- Higher education in tourism

- Higher education in the fields related to tourism (geography, pedagogy, psychology, history, economics)

- Secondary specialized education in tourism

- Education doesn't matter

- Other

Figure 2. Answers to the question about the education

of employees from industry specialists (Source: compiled by the author)

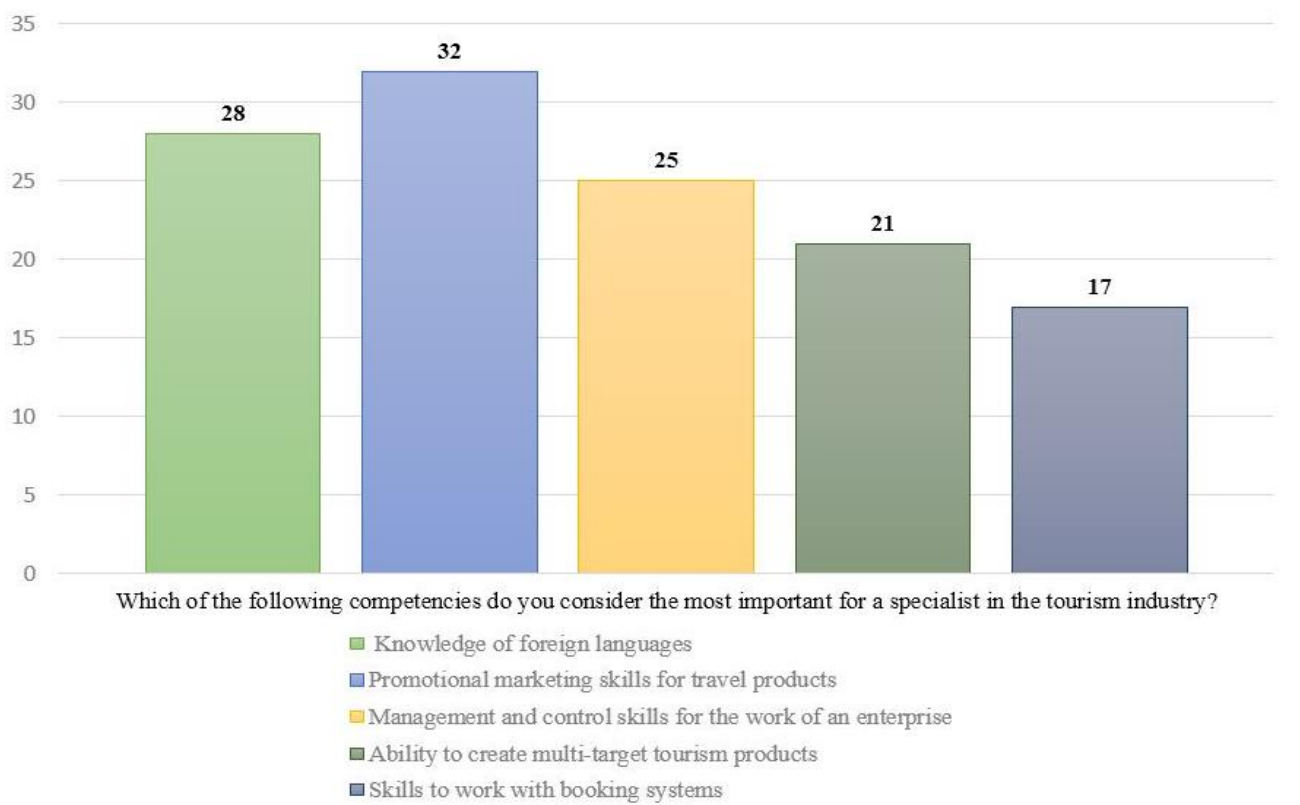

Figure 3. Answers to the question about the most critical competencies of employees from industry specialists. The unit of measure on the axis is the number of responses (Source: compiled by the author)

Republic of Kazakhstan it is the training of specialists in the field of tourism with fully mastered skills of human resource management, who are able to regulate their activities, set their own vector of professional development in accordance with the HRM career model. This position is also supported by the government. In Tourism, the state mandatory standard of education for all levels of education (bachelor's, master's, and doctoral studies), the mastery of skills in managing professional processes, personnel, human resources, and professional self-development holds one of the mandatory positions (The order of the Minister of Education and Science of the Republic of Kazakhstan No. 604 dated October 31, 2018 "On the approval of State mandatory standards of education at all levels of education" registered in the Ministry of Justice of the Republic of Kazakhstan on November 1, 2018 No. 17669). Professional standards developed by Atameken National Chamber of Entrepreneurs in 2017 and in 2019, designed for the creation of educational programs, including for training personnel at enterprises, for certification of employees and graduates of educational institutions, for solving a deep range of duties in the field of personnel management. The entities of the tourism industry, educational organizations that prepare specialists for the tourism industry can develop corporate documents, professional standards for employees with clarification of the professional education level, the list of labor duties, knowledge, skills, taking into account the characteristics of the organization of production, labor and management, their obligations (Appendix No. 1 to the order of the Chairman of the Board of Atameken National Chamber of Entrepreneurs of the Republic of Kazakhstan No. 3 dated January 17, 2017 "Tourism Professional Standard"). The trends of contemporary HRM in tourism and tourism education are directed by the demands of the labor market, the entities of the tourism industry, and the order of the government for the training of professional personnel. The principles of permanent training and lifelong learning have left their mark on all areas of the professional development of experts. Implementing this principle in the training of tourist personnel with HRM skills, the authors have developed a model for the organization, formation, and development of competencies necessary for planning, managing and improving the efficiency of human resources in the companies of the tourism industry (Figure 4). 

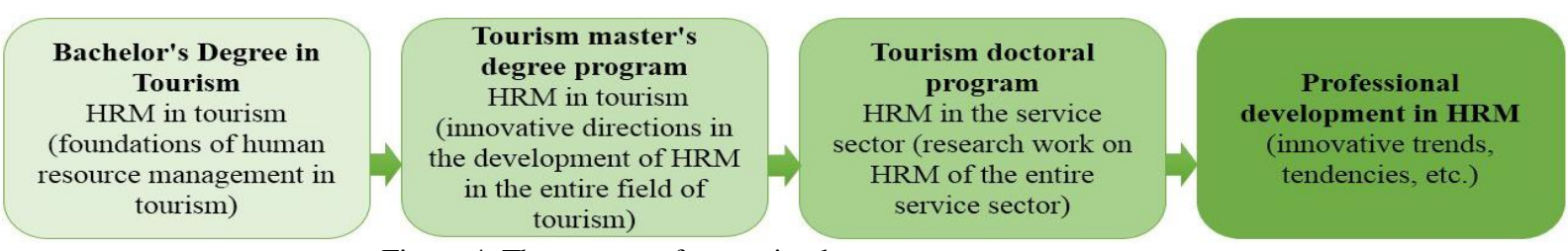

Figure 4. The process of mastering human resource management

competencies in the system of constant tourism education (Source: compiled by the author)

The process of mastering professional competencies in the field of HRM for specialists in the tourism industry should be constant in the system of higher and postgraduate education. Therefore, at the Kazakh Academy of Sports and Tourism, the authors have developed a three-stage model for the Tourism educational program, which is awarded by UNWTO TedQual, the international quality certificate (https://www.unwto.org/institutions-unwtotedqual-certified-programmes):

- Tourism educational program, bachelor's degree level. It includes the discipline of personnel management, human resource management in the field of tourism. Students study the theoretical framework of HRM, analyze the evolutionary path of development of the human resource management system, basic concepts, and specific features in the tourism industry. The discipline shows the basics of a sufficient approach in the search, selection, training, professional activity, development, and evaluation of personnel. The course covers theoretical and practical basics of personnel management, development of an organizational mechanism and planning of personnel demands, psychological and professional training of personnel, management of their motivation in the conditions of the modern tourism industry for gaining a competitive advantage.

- Tourism educational program, master's degree level. The discipline is aimed at deepening the competencies obtained at the bachelor's level. Students examine modern HRM models: competing values, rational goals of internal processes, human relations, open management systems. The peculiarities of HR management in the tourism industries and at the enterprises of the tourism industry abroad and in Kazakhstan. HRM. The principal directions of work with human resources in the entire tourism sector.

- Tourism educational program, the doctoral studies. The discipline is directed at strengthening and developing the competencies obtained at the bachelor's and master's degrees. It reveals the peculiarities of effective human resource management at all types of service enterprises, taking into account the psychology of managerial activity and the organization of interaction processes between internal departments and departments of a tourist enterprise. The course involves the development of economic, organizational and administrative and socio-psychological methods of selection, distribution and development of human capital, as well as methods of automation of personnel management, coordination and quality control of services provided. Doctoral students take an active part in conducting various-level research in the field of innovative areas of the human resource management system in the service sector, thereby developing the possibilities of applying the results of their research activities in contemporary tourism at the regional and international levels.

- Constant professional improvement of specialists at all levels, allows expanding the skills of human resource management, studying innovative fields, exploring the trends of modern HRM in tourism, as well as being active participants in the development of the country's human capital. This model allows active implementation of a human

Which direction of additional education (courses, training, etc.) of a specialist in the tourism industry is more priority for you?

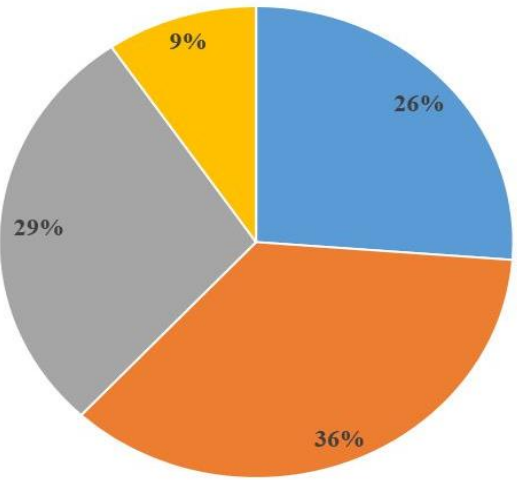

$=$ Tourism instructor $\equiv$ Tour guide $\equiv$ HR specialist $=$ Other

Figure 5. Analysis of the response of professional respondents to the etc.) of a specialist in the tourism industry is more priority for you?" question "Which direction of additional education (courses, training, resource management system in higher education in tourism, thereby preparing specialists, managers who are in demand in the labor market, who have the skills of career building, personnel management, creating innovative methods, and their introduction in the service sector. This position of permanent education or life-long education is also proved by the analysis of the survey results, namely, the answer to the question "Which direction of additional education (courses, training, etc.) of a specialist in the tourism industry is more priority for you?" (Figure 5). Thus, the analysis of the answers to the respondents' question shows that in addition to the main profession of a Travel Manager, specialists of the tourism industry need to have additional qualifications. The most priority answers are: a tour guide - 36\%, an HR specialist - 29\%, a tourism instructor - $26 \%$, and the remaining $9 \%$ are different types of additional qualifications, depending on the specifics of the enterprise in which the respondent works. This analysis proves the trends of modern HR management in tourism and tourism education. Human resource management skills are viewed as one of the most valuable for specialists in the tourism industry. The development of HRM in the Republic of Kazakhstan is taking place at an "accelerated" speed. Currently, specialists in this field are actively exploring multiple development models, based on the data collected, a national model of the unique development of the human resource management system is being built in all areas of professional activity in which a person is involved - as a resource and capital that requires investment and development. Tourism has special importance in the economy of numerous countries and the life of society as a whole, representing a communicative activity; it requires the quality of training of personnel with the knowledge and skills in the human resource management system. 


\section{CONCLUSIONS}

1. In the article, the authors have analyzed the stages of development of the conceptual framework of the human resource management system in tourism of the Republic of Kazakhstan.

2. The authors have conducted the survey among specialists of the tourism industry, which was attended by tourism entities of Kazakhstan, Lithuania, Russia, and Ukraine to discover the need to change the approach to training professionals with HR planning and management skills.

3. The results of the survey have revealed the need for training professionals with HR skills for the tourism industry who are actively involved in the system of innovative tourism development.

During the research and professional activity in the system of higher and postgraduate education, the authors have developed a model of mastering competencies in the human resource management in tourist education.

\section{Acknowledgments}

The results of the research and professional activities of the authors, outlined herein, have become a crucial element in the development of the process of forming the concept of constant tourism education, taking into account the conceptual framework of the human resource management system in tourism of the Republic of Kazakhstan. In the course of the research, the authors have conducted the survey that showed the need for training tourist personnel with professional competencies in HR management, career building, and implementation of the principles of human capital development.

\section{REFERENCES}

Abdikarimova, M.N., Gubarenko, A.V., Makogonov, A.N., Imangulova T.V., \& Luterovich, O.G. (2020). A systematic approach to the development of educational trajectories for training tourism industry specialists for excursion services. Scientific-theoretical journal "Theory and Methods of Physical Culture", 4(62), 32-40.

Anderson, N., Potočnik, P., \& Zhou. J. (2014). Innovation and creativity in organizations: a state-of-thescience review. Journal of Management Studies, 40 (5), 1297-1333. https://doi.org/10.1177/0149206314527128

Ardito, L., \& Messeni, P.A. (2017). Breadth of external knowledge sourcing and product innovation: The moderating role of strategic human resource practices. European Management Journal, 35 (2), 261-272. http://dx.doi.org/10.1016/j.emj.2017.01.005

Armstrong, M. (2019). The main HR textbook in the world (translated from English by Begma E.L.), Moscow, Eskimo, pp. 416, (in Russian).

Armstrong, M. (2004). Handbook of Human Resource Management Practice. 8th ed., St. Petersburg, pp. 20, (in Russian).

Arpentieva, M.R., Gorelova, I.V., Kassymova, K.G., Lavrinenko, S.V., Shumova, K.A., Malinichev, D.M., Simonov, V.L., Kosov, A.V., Garbuzova, G.V., \& Stepanova, O.P. (2020). Human resource management and dynamic capabilities of educational enterprises: psychological, social and economical aspects. Bulletin the National Academy of Sciences, 1(383), $242-254$. https://doi.org/10.32014/2020.2518-1467.30

Bazazo, I.K., \& Alananzeh, O.A. (2020). The implementation of international standards and specifications on improving the quality of Diving tourism in Aqaba, Jordan. GeoJournal of Tourism and Geosites, 33(4), 1557-1563. https://doi.org/10.30892/gtg.334spl17-608

Boxall, P., John, P., \& Patrick, M. (2009). Wright 1. Human Resource Management, Peter Boxall, John Purcell, Patrick M. Wright, Oxford University Press, 2009-09-02.

Cheglakova, A., \& Chislina I., (2019). The importance of modern HRM systems in enterprise management. Innovative economy: prospects for development and improvement, 6(40), 139-145, (in Russian).

Erdavletov, S.R. (2000). Geography of tourism: history, theory, methods, practice. Almaty, pp. 336, (in Russian).

Hamdamov, S.I.O. (2020). Methods of managing the innovation potential of the region taking into account the key role of human capital in the transformation of resources into innovation. Capital of Science, 10(27), C., 40-45.

Israilova, A.M. (2020). Comparative analysis of methodology and approaches in human resource management. Proceedings of the Issyk-Kul Forum of Accountants and Auditors of Central Asian countries, 1(28), 58-68, (in Russian).

Karamova, A.S. (2014). Human Resource Management for the Tourism Industry. Economics and management of innovative technologies, 3(1), Electronic resource, (accessed: 06.23.2021). https://ekonomika.snauka.ru/2014/03/3685

Mahmoud, R., Al-Mkhadmeh, A.A., Alananzeh, O.A., \& Masa'deh, R. (2021). Exploring the relationship between human resources management practices in the hospitality sector and service innovation in Jordan: the mediating role of human capital. GeoJournal of Tourism and Geosites, 35(2), 507-514. https://doi.org/10.30892/gtg.35231-678

Morgunov, Y.B. (2011). Personnel Management: Research, Evaluation, Training. M. Youwrite Publishing House, pp. 561, (in Russian).

Olimova, (2021). Improvement of the human resources management strategy in the enterprises of the real sector. Cognitio rerum, 7, C, 25-28.

Rudenko, A.M. (2015). Human Resource Management: a textbook. Rostov-on-Don: Phoenix, pp. 350, (in Russian).

Shapiro, M.G. (2017). Classification of Survey Methods in Sociology / Social Research, 2, 51-59, (in Russian).

Tokayev (2020) The Address of the Head of State Kassym-Jomart Tokayev to the people of Kazakhstan. https://www.akorda. kz/ru/addresses/addresses_of_president/poslanie-glavy-gosudarstva-kasym-zhomarta-tokaeva-narodu-kazahstana-1-sentyabrya-2020-g

Vasyuchkova, O.I., Golikova Z.A., Dolgorukova, A.I., Kovalenok, T. V., Khvashchevskaya, L. D., Khvedchenya, L. V. (2017). English for Research Students. Study-method manual for undergraduates, 2nd ed., supplement and revision, Mn., BSU, pp. 186, (in Russian).

*** The order of the Minister of Education and Science of the Republic of Kazakhstan. (2018). No. 604 dated October 31,2018 "On the approval of State mandatory standards of education at all levels of education" registered in the Ministry of Justice of the Republic of Kazakhstan on November 1, 17669.

*** Appendix No. 1 to the order of the Chairman of the Board of Atameken, the National Chamber of Entrepreneurs of the Republic of Kazakhstan. (2017). 3, "Tourism Professional Standard".

*** https://www.unwto.org/institutions-unwtotedqual-certified-programmes

Article history: Received: 10.05.2021 Revised: 09.08.2021 Accepted: 14.09.2021 Available online: 06.10.2021 